\title{
Ön-Rönesans Dönemi Resim Sanatının Özellikleri ve Temsile Dönük Cağdaș Resim Sanatı Üzerindeki Etkileri
}

Hamdi GÖKOVA*

Özet

Ön-Rönesans dönemi, Rönesansa giden yolda doğal gerçekliğin akla uygun betimlenmesi açısından sancılı bir süreçtir. Doğanın perspektif aracılığılla iki boyutlu düzleme aktarılmasında yaşanan sıkıntılar, oylumlamada iki boyutluluk hissinin tam olarak aşılamaması ve hala Ortaçağ sanatının sembolik dilinin varlı̆ııı sürdürüyor olması buna neden olan etmenlerdir. Ama bu ikircikli sonuçlar bu dönem resimlerinin karakteristik özellikleridir ve güçlerini, samimiyetlerini, referans olma özelliklerini de bu niteliklerinden alırlar. Rönesans’ın olgun dönemindeki kazanımlar zamanla akademilerde tartışmasız bir öğreti haline gelir. Teknik yetkinlikle yapılan mekanik tekrarlar sanatın yüzeyselleşmesine, samimiyetinin ve yaşamsallığının kaybolmasına neden olur. Akademik sanata gösterilen tepkiler sonucunda ön-Rönesans resimleri ilgi görmeye başlar ve bu ilgi ilk ortaya çıktığından çağımıza kadar temsile ve figürasyona yönelen her sanat hareketinde varlığını ortaya koyar.

Anahtar Sözcükler: Ön-Rönesans, Temsil Resmi, Modernizm, Postmodernizm, Çağdaş Sanat.

\section{The Characteristics of Pre-Renaissance Painting Art and Its Influence on Representative Contemporary Painting Art}

\section{Abstract}

The Pre-Renaissance era was a problematic period with regard to the depiction of reality in a rational way. Artists were facing issues concerning using perspective to depict nature on a two-dimensional surface; they were not quite able to create fully the illusion of depth in modeling, and the symbolic visual language of Medieval Art was still quite dominant. However, these ambivalent results are a characteristic of the paintings of this era, which take their power, sincerity and uniqueness from these qualities as well. The progress made in the mature period of Renaissance has since become an indisputable doctrine in academic circles. Yet, mechanical repetitions with technical proficiency has resulted in art becoming superficial and losing its sincerity and indispensability. The criticisms against academic art has renewed the interest in Pre-Renaissance art, which has since influenced every art movement that is representative and figurative.

Keywords: Pre-Renaissance, Representative Painting, Modernism, Postmodernism, Contemporary Art. 


\section{Giriş}

Sanatın tarihi temsilin de tarihidir. Sanat tarihsel süreç içinde gerçeklik algısındaki değişmelere paralel biçimde sanatsal temsil de değişime uğrayarak gelişimini sürdürmüştür. Ortaçağda dini öğretiyi temel alan bir anlatımcılığa ve sembolizme sahip olan, Rönesansta hümanizm nedeniyle insana yönelen ve idealizasyonu içeren temsilin koşulları modernizmle birlikte köktenci bir değişime uğramış “....resimsel mekan yanılsama ve yansıtma mekanı olmaktan çıkıp zaman mekan olgusunu da yerleştirerek resimsel bir mekan olarak yeniden kurulmuştur... artık temsil salt dış gerçekliğin değil, duygu ve düşüncenin temsili olmuştur” (Alp, 2013: 41). Postmodern süreçte ise modernizme yönelik eleştirel tutum bağlamında yeni temsil olanakları gündeme gelmiştir. Soyut ve soyutlamayı da içeren geniş bir kapsama sahip olan temsil kavramı, bu çalışmada daha çok doğa gerçekliği ve onun temsili anlamıyla kullanılacak ve referanslarını figür plastiğine yönelik çalışmalar oluşturacaktır.

Resim sanatında 19. yüzyılın ikinci yarısından başlayarak artan bir ivmeyle devam eden ve 20. yüzyılın başında şaşırtıcı bir hızla ortaya çıkan köktenci değişimler çeşitli kültürel-etnik kökenlerle ve sanatsal gelenekle kurulmuş olan yeni bağlantılara çok şey borçludur. Bu bağlamda ilkellerin sanatı ve egzotizm kübizme ve dışavurumculuğa ilham verirken, Bosch ve Bruegel sürrealist oluşuma önemli katkılarda bulunmuşlardır. Kendi döneminde ve daha sonraki beş yüz yıl boyunca yadırganan El Greco'nun abartı ve deformasyona dayalı biçimlendirme yöntemi özellikle dışavurumculuğu etkilemiştir. Öte yandan gerçekliği yeni bir bakış açısıyla değerlendiren çağdaş resimsel yaklaşımlar (Metafizik resim, Sürrealizm, Yeni nesnelcilik gibi) ise özellikle Cimabue ile başlayan, Giotto ile gelişerek devam eden ve erken 15. Yüzyıl (Quattrocento, 1400'lü yıllar) İtalyan ressamlarının çalışmalarında görülen gerçekliğin kavranmasına dönük çabaların ikircikli sonuçlarından esinlenmiştir. Quattrocento dönemi ressamlarının çalışmaları, gücünü, samimiyetini ve referans olma niteliğini tam da bu noktadan alırlar. Bu dönem sanatçılarının bütün çabalarına rağmen aşamadıkları iki boyutluluk hissi 20.yüzyıl sanatçılarına soyutlamaya giden yolda da rehber olmuştur. Bu çalışmanın amacı, soyut ve soyutlamaya dönük modernizm sürecinden çok gerçekçilik temelli çağdaş resimsel oluşumların Ön-rönesans dönemiyle (ya da bilinegelen ifade tarzıyla söylemek gerekirse, betimlemeci geleneksel tavırla) olasılık dahilindeki bağlantılarının izini sürmektir.

\section{Ortaçağ ve Ön-Rönesansta Resim Sanatının Karakteristik Özellikleri}

Rönesans’a doğru giden yoldaki resimsel hedef, perspektif aracılığıyla doğanın tasviri ve figürlerin ayaklarının yere sağlam bir biçimde bastığı görsel çözümlere ulaşmaktır. Bunun başarılması zaman almıştır, çünkü bu dönemde pek çok sanatçı yeni kuralların uygulanışında özellikle de perspektif konusunda zorluklar yaşamışlardır. Erken-Rönesans ressamlarının perspektifte sorun yaşamalarının temel nedeni, yüzyıllar boyunca Uluslararası gotik ve Bizans sanatının etkileri altında kalmış olmalarındandır. Resimsel mekanın perspektifle kavranmasına dair buluşların uygulanışındaki zorluklar yüzeye dönük, iki boyutlu sembolik mekan anlayışını kırmanın güçlügüünden kaynaklanmıştır. Rönesans öncesinde kuzey Avrupa ülkelerinde daha çok Gotik sanat etkisini sürdürürken İtalya'da yoğun bir Bizans (Vasari'nin deyimiyle Yunan) etkisi vardır. Sadece İtalya'da değil dolaylı da olsa 6. ve 11. Yüzyıllar arasında Avrupa'da da bu etki görülmüştür. Ama İtalya ile Bizans arasındaki daha sıkı ilişkiler nedeniyle bu etki İtalya'nın belli bölgelerinde daha fazla hissedilmiştir. Bizanslı ustalar İtalya'da uygulamalı eğitimler yaparak mozaik, ikona ressamları yapmışlardır. "Bizans şemalarına bağlı ya da bu ikonografyadan önemli izler taşıyan mozaiklerin yapımında yerli veya Bizanslı ustalara yer verilmiştir. 12. yüzyılda İtalya'da doğan (İtalo-Bizanten) diye adlandırılan tasvir tarzı bütün bu gelişmelerin neticesidir” (Beksaç ve Akkaya, 1990: 40-41). Bu akım en çok eski Bizans toprağı Sicilya ve Venedik’te etkili olmuştur. Bizans sanatı antik gelenekten tam olarak kopamadığı için bütünüyle çizgisel ve iki boyutlu bir dünya değildir ve bu konuda kararsızlık sergilemiştir. "Bizans sanatı bütündeki düzensizleşmeye rağmen ... antik perspektifin mekan yapısının tekil unsurlarını koruyabilmiş ve onları Batı Rönesansı için hazır tutabilmiştir” (Panofsky, 2017: 33).

Vasariye göre Yunan (Bizans) geleneğinden uzaklaşılmasıyla birlikte Rönesans'ın ve yeni sanatın yolu açılmıştır. Bizans üslubundan vazgeçme aşamasında;

...ilk adımları Cimabue atmış, onu Giotto takip etmişti- ve 
onun yerini yeni bir üslup aldı; ben bunu Giotto'nun kendine özgü üslubu olarak adlandırmaktan hoşlanıyorum çünkü bu üslup, o ve öğrencileri tarafından keşfedildi ve daha sonra genel bir hayranlık uyandırarak herkesçe taklit edildi. Bu resmetme üslubunda kesintisiz konturlar, dik dik bakan gözler, parmak ucuna basan ayaklar, pürüzsüz eller, gölgenin bulunmayışı ve öteki Bizans’a özgü saçmalıklar dışarıda bırakılmıştı; onların yerini zarif başlar ve hoş bir renklendirme almıştı (Vasari, 2013: 77).

Giotto (Giotto di Bondone: 1266?-1337) ve Duccio'nun (Duccio di Buoninsegna: 1255-1319) çalışmaları sayesinde antik çağdan beri engellenen 'içinden geçerek bakış' tekrar açılmış ve ortaçağın temsil ilkesi de böylece aşılmaya başlamıştır. İç mekan artık nesnelerin yan yana getirilerek güçlendirilmesinden daha fazlasına işaret etmekte, “üzerine tekil nesne ya da figürlerin aktarıldığı bu yüzey artık bir duvar ya da pano olmaktan çıkmış, tekrar şeffaf bir düzlem haline gelmiştir ve bizden beklenen de bu düzlemin içinden geçerek her ne kadar her tarafından sınırlanmış olsa da içeriye doğru uzanan mekana, boşluğa baktığımıza inanmamızdır: Bu düzlemi kelimenin tam anlamıyla 'resim düzlemi' olarak tanımlayabiliriz" (Panofsky, 2017: 39). Bu aşamada bütünlüklü bir perspektif mekan anlayışından söz edilemese de kuramsal bilgi ve doğa bilimlerinde elde edilen başarılar, perspektif konusundaki gelişmelerin yolunu açmış, yığma mekandan sistematik mekana geçilmiştir.

Giotto'nun yapısalcı yaklaşımı ve diyagonal çizgilerle elde ettiği derinlik duygusu o dönem sanatında bir yeniliktir. Yapısalcı tutum, figürlerin durağanlaşmasına neden olmuş ancak bu durum onların tuhaf bir enerjiye sahip olmalarını da sağlamıştır. “Giotto'nun figürlerinin sağlam strüktürü onlara öyle bir karakter vermektedir ki, bu figürler hakikaten hareketten mahrumdur. Hareketten mahrumdur, fakat enerjiden değil” (Venturi, 1954: 26). Bu resimler enerjilerini durağanlığın oluşturduğu gerilimden alırlar. Giotto tüm ortaçağ boyunca tanrıyla uğraşan bir medeniyet dönemine son verip, insanla uğraşılan bir uygarlık döneminin yolunu açmıştır. İlahi denilen şeyin bizzat insanın içinde olduğunu görmüştür. Bizans ve ortaçağ sanatından kopuş adına ciddi bir mesafe kat etmesine rağmen "Giotto fizik güzelliğe değer verebilmek için haddinden fazla spritüel, semavi güzelliğe ehemmiyet vermek için ise haddinden fazla beşeri idi” (Venturi, 1954: 36).

Giotto Rönesansa açılan kapıyı aralamış, Masaccio (1401-1428) da bu kapıyı sonuna kadar açmıştır. Masaccio figürleri gerçek anlamda yere bastırmıştır. Giotto'nun figürleri rölyef etkisine sahipken, Massaccio'nun figürleri heykelsi bir etkiye sahiptirler. Masaccio duvara delik açmak denilen, derinlik yaratma, göz aldanımı ve kısaltım (rakursi) konularında önemli buluşlara imza atmıştır. Onun kısacık yaşamında loş köy kilisesinde (Santa Maria del Carmine kilisesi içinde Brancacci şapeli) gerçekleştirdiği çalışmalar Rönesansın bütün önemli ressamlarının eğitiminde büyük bir rol oynamıştır.

Paolo Uccello'nun (1397-1475) daha çok çizgisel perspektif yoluyla resimsel derinliği elde etme çabaları tuhaf sonuçlara yol açmıştır. Brunelleschi'den (1377-1446) öğrendiği çizgisel derinlik çizimi ve perspektif araştırmalarına kendisini öylesine kaptırmıştır ki figürlerinin mekanla ilişkisi sorunlu hale gelmiş, resimsel bütünlüğü oluşturmada sıkıntı yaşamıştır. Onun çalışmalarının bu şekilde sonuçlanması hala Uluslararası Gotik üslubunun etkisi altında olmasındandır. Öte yandan Uccello'nun çabası o esnada Floransa atölyelerindeki yeni arayışları yansıtması açısından önemlidir. Bu dönemde sanatçıların perspektif konusunda ustalıklarını sergilemek adına konuyu bile unuttukları anlatılır. Sanatçının Floransa ile Siena şehir devletleri arasında 1432'de gerçekleşen savaşı canlandırdığı 'San Romano Savaşı' adlı resmi hem ÖnRönesans'ın hem de kendi sanatsal üslubunun anlaşılması açısından önemli bir örnektir (Resim 1).

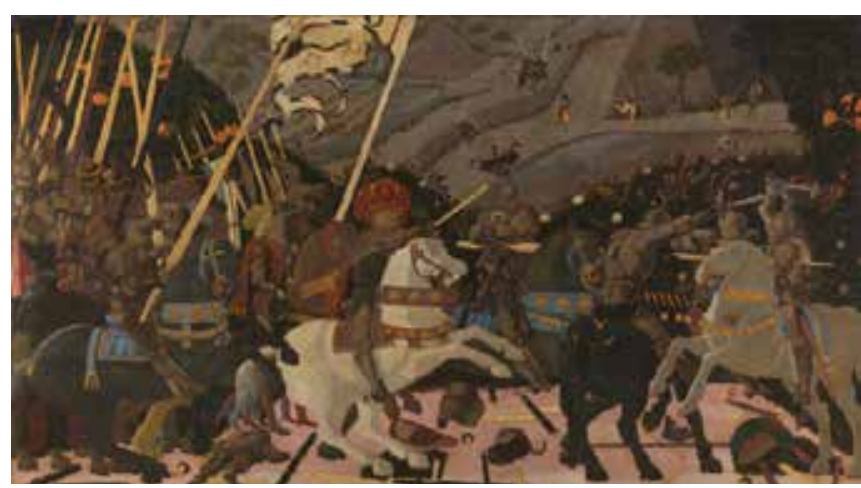

Resim 1. Paolo Uccello, 'San Romano Savaşı', 1438-40, Ahşap Üzerine Tempera, $182 \times 320 \mathrm{~cm}$, The National Gallery, London https://www.nationalgallery.org.uk/paintings/paolo-uccello-thebattle-of-san-romano Erişim: 20.12.2017 
Floransa'daki Medici Sarayının bir odası için yapılmış olan bu resim üç panelden oluşmaktadır. Burada inceleme konusu olan Londra Ulusal Galeride bulunan ilk parçadır. Diğer parçaların birisi İtalya Uffizi Müzesi'nde, öteki ise Fransa Louvre Müzesi'ndedir. Hepsi de yaklaşık aynı boyutlardadır $(182 \times 320 \mathrm{~cm})$. Oda duvarlarının eteklikleri için ahşap üzerine tempera ve yağlıboya ile gerçekleştirilmiştir. Derinlemesine bir doğa gözleminin eksikliği resmin geri planında naif bir tutum sergilenmesine, çizgisel perspektif yoluyla kısmi bir derinlik hissi yaratılmasına neden olmuştur. Kırılıp yere düşen savaş gereçleri ısrarla kaçış noktasına yönlendirilmiş, yerde yalnız başına uzanmış yatan asker kısaltım prensiplerine uygun betimlenmesine rağmen çevresiyle oransal ilişkisi sorunlu bırakılmıştır. Işık ve gölge temelinde bir boyutluluk yok hatta bu resimde hiçbir nesnenin gölgesi de yoktur. Olumsuzluk gibi görünen bu özelliklerine rağmen bu resim tuhaf bir çekim gücüne sahiptir. Kukla gösterisi ya da gölge oyunu gibi sonuçlar doğuran bir görselliğe sahip olan bu çalışmanın özellikle sembolist oluşuma yol gösterdiği söylenebilir. Onun resimleri devinimsel dramı derinlere indiren ya da açıp yayan düz çizgilerin sinirli gücüyle etkileyici güzelliğini arttırdığı hemen hemen soyut bir zemin üzerine düşen canlı gölgelerdi. Uccello'nun güçlü canlılığı bütün ötekilerden çok çok önce ve ta Michelangelo döneminin sonuna dek Piero della Francesca ve Signorelli aracılığıyla İtalyanların soylu çağına can verecektir (Faure, 1979: 38-41).

Piero Della Francesca (1416?-1492) perspektif ve derinlik sorunsalını Uccello ve Masaccio'dan biraz daha farklı bir biçimde ele almıştır. Resimlerindeki bağlantıları Öklit geometrisine dayandırmış ve düzgün çokyüzlülere dönük araştırmaları aracılığıyla doğanın düzenine dair ölçülebilir bağıntılar oluşturmaya çalışmıştır. "Piero resim ve perspektif üstüne çok yoğun araştırma yapmıştı. Öklid'i derinlemesine biliyordu, düzgün çokyüzlülere dayanarak çizilen mükemmel eğrilerin niteliğini herkesten iyi kavramıştı ve bu konudaki en net açıklamalar onun kaleminden çıkmıştı" (Vasari, 2013: 166). Bu araştırmalarının sonucu olarak sanatçı resimlerinde doğayı ve figürleri de geometri ilkelerine uydurmaya çalıştı. Onun Diriliş adlı resmi (Resim 2) piramit formu temel alınarak oluşturulmuş, yukarıdaki köşede İsa'nın başı yer almış, alttaki köşelere yatay bir düzlem boyunca askerler yerleştirilmiştir. İsa'nın vücudu ışığı temsilen sarı ve açık tonlarla çalışılmış ve sert kenar çizgileriyle koyu fondan ayrılmıştır. Masaccio'daki derinlik etkisi Piero'da yoktur. Buradaki figürler ya da görsel unsurlar, renk ve biçim kontrastlığı gözetilerek ve hiyerarşik bir düzen içinde ele alınarak görselleştirilmiştir.

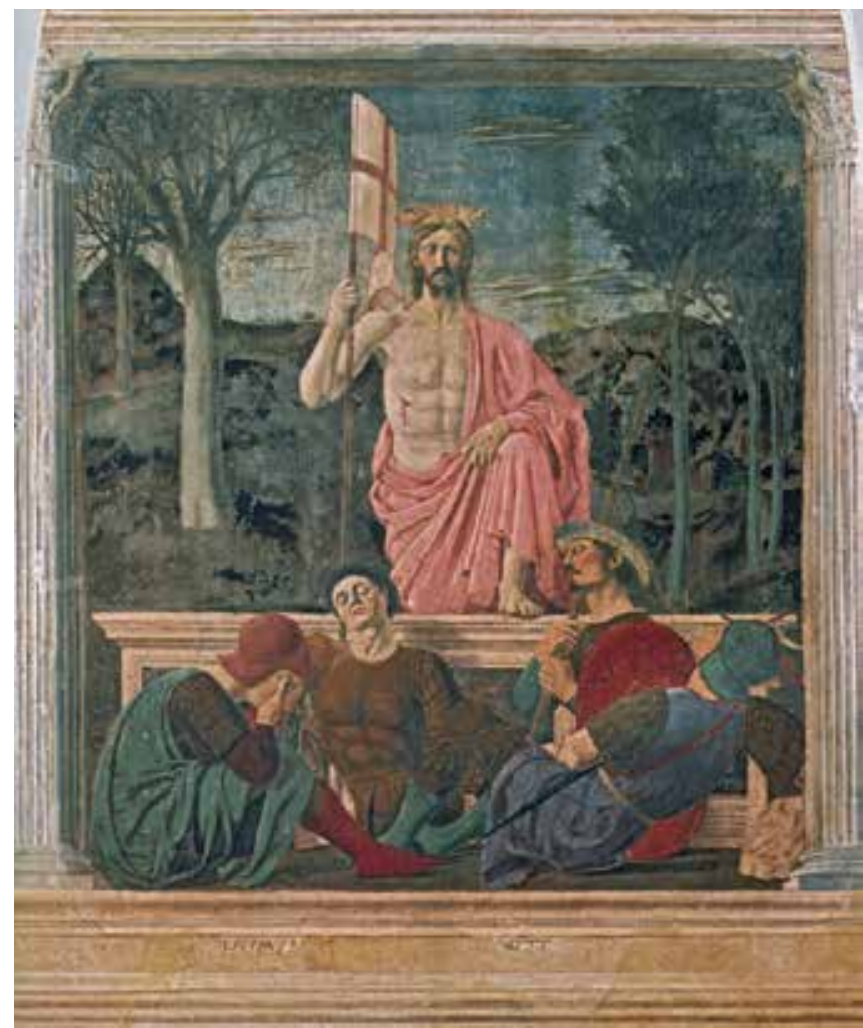

Resim 2. Piero Della Francesca, 'Diriliş', 1460, Fresk-duvar, Museo Civico di Sansepolcro, Italy

https://www.wikiart.org/en/piero-della-francesca/theresurrection Erişim: 20.12.2017

Piero Della Francesca "ilahi olanın asilliğini, ümanistik ideali, insan vakarını, insanın kainatın merkezi olduğu fikrini mükemmelen hazmetti; fakat kudret ve enerji ifadesi arayacağ yerde, vakur bir sükunetin ve zerafetle dolu bir ihtişamın rüyasını gördü. Onun yaptığı şey sembolik imajların tasviridir" (Venturi, 1954: 47-48). On dokuzuncu yüzyılın akademik sanat karşıtı hareketleri ve figüratif yönelimlerde bu sanatçı öncü figür olma özelliğini korur.

Sandro Botticelli'nin resimleri (1445-1510) çizgiselliğin lirizmine sahiptirler. Bu çizgisel tutum figürleri yüzeyde tutar. Botticelli, yapısalcı bir yaklaşım yerine arabesk formlar aracılığıyla hareketi ve dinamizmi vurgulayan dekoratif bir resimsel tutum ortaya koyar. Bu da figür yorumlarında deformasyon ve abartının ortaya çıkmasına neden olur, onun lirizmi ve zarafeti de işte bu anda ortaya çıkar. Yaşadığı dönemde hala ortaçağın doğal simgeciliğinin devam ediyor olması onun da diğer ön Rönesans sanatçıları gibi sancı ve ikilem yaşaması- 
na neden olmuştur. Çizime dayalı ifade olanaklarını devreye soktuğu simgeci figüratif yaklaşımının yansımalarını Nabiler, sembolistler ve Art Noueau sanatçılarının çalışmalarında görürüz. Hatta Modigliani’nin figür yorumlarında ve çizim anlayışında da onun izlerine rastlamak mümkündür.

İtalya'daki Ön-Rönesans sürecine rastlayan dönemde İtalya'nın kuzeyindeki ülkelerde ve Felemenk ülkelerinde Gotik sanat hala etkilerini sürdürüyordu. Hubert ve Jean van Eyck kardeşler dua kitaplarının resimlenmesi işinde ustalaşarak olgun Gotik sanatın en yetkin örneklerini ortaya koymuşlardır. Yavaş ve detaylı çalışmanın gerektirdiği yağııboya tekniğini de Eyck kardeşler resim sanatına kazandırmışlardır. "Kitapları resimleyen sanatçılar ancak yağlıboya resim aracılığıyla boyanan beze duruluğu, saydamlığı, kuzey ışığının derin ve tatlı parlaklığını, kapalı göklerin ışığını, pırıl pırıl sürülmüş tarlaların, ıslak ormanların, alabildiğine solgun bir güneşin bastıramayacağı ışığını katabilmişlerdir” (Faure, 1979: 222-223).

Uluslararası Gotik, kilisenin Fransa denetimine geçmesi ve papalık makamının da Avignon'a taşınmasıyla birlikte Avrupalı sanatçıların etkileşimi sonucunda melez bir üslup olarak feodalitenin ve dolayısıyla Roman sanatının silinmeye yüz tuttuğu anda ortaya çıkmıştır. Kırsal kökenli feodal yaşamdan kent yaşamına geçiş, tüccar ve üreticilerin feodal yöntemlerle çatışması sonucu ortaya çıkan birlikler ve loncalar kent yönetiminde etkin olmuş, yavaş yavaş da ulus devletler oluşmaya başlamıştı. Görkemli gotik yapıtları, oluşan bu kent yöneticilerince desteklenmiş kırsaldaki Roman kiliseleri yerini kentlerdeki Gotik katedrallere bırakmıştır. Yeniden doğuş anlamındaki Rönesans'a has buluşların kuzey ülkelerindeki yansımaları bir bakıma bu Gotik gelenekle iç içe geçmenin sonucunda gerçekleşmiştir. İtalyan sanatındaki coşku, tensel haz ve dünyevilik kuzeyli sanatçılarda yoktur ancak onlar başka türden insani bir boyut ortaya koyarlar; detaylara verdikleri önem onların sanatını maddi benzerlikle birlikte manevi bir boyuta da taşır. Fransa'da bir süre sonra kaybolan ve İtalyanların da fazla yüz vermediği Gotik sanat Almanya'da her zamankinden daha uzun yaşadı. Ortaçağ zanaatçılarıyla yan yana çalışan Alman sanatçılar baskı resim konusunda öncü olmuşlar ve bunu geliştirmişlerdir. "Bakır üstüne oymabaskı resim yapmakta Dürer'den, ağaç üstüne de Holbein'den daha ustası gelmemiştir” (Faure, 1979: 302). Alman sanatının çizgiye dayanan anlatımcı ve sembolik yapısının biraz da bununla ilgili olduğu söylenebilir.

\section{Perspektif; Kuralların Uygulanması ve Yaşanan Kimi Sorunlar}

Antik Yunan ve Roma dönemlerinden bu yana bilinegelen perspektif Hristiyanlık çağıyla birlikte ortadan kaybolmuş, Rönesansla birlikte yeniden gündeme gelmiştir. "İlk İtalyan sanat tarihi yazarlarından Lorenzo Ghiberti, Leone Batista Alberti ve özellikle de Giorgio Vasari, klasik sanatın Hristiyanlık çağının başlangıcında yıkıldığı ve Rönesans çağının başlangıcına kadar da canlanamadığı düşüncesindeydiler" (Panofsky, 1995: 49). Bunun temel sebepleri, barbar ırkların istilaları ve Hristiyan papaz ve bilginlerinin bu sanata karşı düşmanlıklarıdır. Ancak klasik kavramlar ve gelenekten kopuş hiçbir zaman olmamıştır. “Örneğin, Orpheus figürü David'in betimlenmesi için kullanıldığında, ya da Cerberus’u sürükleyerek Hades’ten çıkartan Hercules tipi Adem'i yeraltından kurtaran İsa'yı betimlemek için kullanıldığında olduğu gibi." (Panofsky, 1995: 51-52).

P. Uccello, Piero Della Francesca, Massaccio gibi ÖnRönesans dönemi sanatçılarının perspektif konusundaki yoğun araştırma ve denemeleri sayesinde Rönesans sanatçıları doğa gerçekliğini üç boyutlu olarak başarılı bir biçimde yansıtabilir hale geldiler. Ancak uygulamada kuzey ülkelerinde ve İtalya'da farklı sonuçlar ortaya çıkıyordu. İtalyanlar hemen hemen bütün iç mekan resimlerinde merkezi kaçış noktasını tam ortaya yerleştirerek "daha çok ön yüzeyi çıkarılmış bir mimari dış mekan" (Panofsky, 2017: 54) ortaya koyarlarken Alman sanatçılar (özellikle Dürer) merkezi kaçış noktasını ikircikli konumlara (sağa veya sola) kaydırarak daha hakiki bir iç mekan gösteriyorlardı. Buradaki temsil içeri henüz yeni girmiş bir izleyiciyi de mekanın içine alan bir etkileyiciliğe sahiptir.

Perspektif, yüksek Rönesans döneminde doğanın gerçekçi ve akla uygun ele alınışında önemli bir rol üstlenmiştir. Ancak daha bu aşamada bile katı perspektif kurallarının dışına çıkıldığına çoğu kez tanık olunmuştur. Bu açıdan bakıldığında perspektif kurallarından sapmalar her sanat eserinde görülebilir, bunu hata olarak görmek doğru değildir, bu temsili sanatın doğasında var olan bir durumdur. "Temsili sanatın görevi bütünlüğü olan belli bir mekansallık farklı, kendi içine kapalı bir dünya sunmaktır. Bu mekanik değil içsel güçler sayesinde çerçevenin sınırları içinde tutulması gereken bir dünya olmalıdır, sanatçının yerine getirmesi gereken birincil ödev, malzeme olarak ayırdığı bir mekan kesitini kendi içine kapalı bir bütüne dönüştürmektir” (Florenski, 2013: 99). 
Perspektif bütünlüğü yani tek odak noktasını amaçlayan pek çok ünlü sanatçı bunu bozmak zorunda kalmıştır. Leonardo’nun ‘Son akşam yemeği’ resmindeki “yemek salonu sadece iki insan yüksekliğinde ve üç insan genişliğindedir; dolayısıyla mekan ne orada bulunan insanların sayısına ne de olayın anlamına uygun düşer” (Florenski, 2013: 91). Yanı sıra Rafaello Atina Okulu resminde figürler ve mekan arasındaki ilişkiyi dengeleyebilmek için;

... iki farklı ufuk çizgisine doğru yönelen iki ayrı durma noktası kullanmıştır. Üstteki durma noktasından hareketle tabanın ve insan grubunun tümünün çizimi, buna karşılık alttakinden hareketle binanın tümü ve resmin üst kısmı yapılmıştır. ......Bu kusurlu perspektifi gizlemek için Raffael, hareket halindeki kişileri mekanın derinliğine yerleştirmiş, böylece ufuk çizgisine doğru ilerleyen taban çizgilerini gizlemiştir (Florenski, 2013: 93).

Aslında uygulamada yaşanan bu zorluklar perspektif konstrüksiyon ile gözün retina imgesinin farklı olmasından kaynaklanmaktadır. Retina imgesi, perspektifle yapılan konstrüksiyonun düzleştiriciliğinden ve tek bir noktadan bakışından farklı olarak "sabit tek bir gözle değil, sürekli hareket eden iki gözle gördüğümüzü, böylece 'görüş alanı'mızın küremsi bir şekil aldığını" (Panofsky, 2017: 13) ortaya koymakta, biçimleri düz değil içbükey yüzeye yansımış görüntüler olarak tespit etmektedir. Bu bağlamda doğanın kusursuz bir perspektif derinlikle temsili mümkün görünmemektedir. Hatta bu Pavel Florenski'ye göre gerekli de değildir. Ona göre perspektif ortaçağda ya da kullanılmadığı dönemlerde becerilemediği için değil, bilinçli olarak kullanılmamıştır. "Sanatsal yaratımda perspektifin kullanılmadığı tarihsel dönemlerde temsili sanat yaratıcılarının perspektifi 'becerememesinin' kesinlikle söz konusu olmadığı, aksine basitçe, bunu kullanmak istemedikleridir" (Florenski, 2013: 75). Florenski ikonalarda ve dini resimlerde göze çarpan perspektife aykırı biçimlendirme özelliklerinin tümünü "tersten perspektif" olarak nitelendirir ve bunların bilinçli bir biçimde uygulandığını belirtir. Çağdaş temsil resminin bu damardan da beslenmesi gerektiğini öne sürer.

Bütün bunların sonucunda çağdaş temsil resmine yönelik arayışlarda, Rönesans’ın doğanın ülküselleştirilmiş perspektif aracılığıyla tasviri yerine, Ön-Rönesansın perspektif açısından sorunlu gibi görünen ancak yüzeyi inkar etmeyen, samimi ve sembolik tutumunu koruyan biçimlendirme anlayışı refe- rans olarak alınmıştır. Çağdaş temsil resmi perspektifi inkar etmez ancak yeterli bulmaz, bu yüzden perspektif resimsel biçimlendirme araçlarından sadece biri haline gelir.

\section{Modernizme Giden Yolda Ön-Rönesans Sanatının Rehberliği}

Rönesans döneminde elde edilen resimsel kazanımlar zaman içinde belirli bir öğretiye dönüşerek akademik sanat anlayışının oluşumuna yol açar. Başlangıçta heyecan verici olan bu buluşlar zamanla Roma ve Fransız akademilerinde tartışmasız bir öğreti haline gelir ve mekanik tekrarlara dönüşerek klişeleşir. Teknik düzeyde yetkinleşmenin getirdiği yüzeysellik, yaşamdan uzaklaşma ve samimiyet eksikliği, akademik sanata karşı tepkilerin doğmasına neden olur. Modernizme doğru giden yolda bu tepkisel hareketlerin rolü büyüktür. On dokuzuncu yüzyıl başlarında Almanya'da kendilerine Nasıralılar (Nazarenler) adını veren sanatçılar akademik sanattaki inanç yoksunluğunu bahane ederek Alman sanatını Hristiyanlık temelleri üzerine inşa etmeyi amaçlamışlardır. Bunun için önerdikleri, Quattrocento ressamlarının samimi ve saf primitivizmi ile Dürer ve Alman primitiflerinin resimsel tutumlarıdır. Edebiyatla yakın ilişkide olan bu sanatçılar ışığın metafizik etkisi ve renklerin sembolik değerlerini vurgulamayı amaçlamışlar ve bunu yaparken hala ortaçağ sanatının sembolik unsurlarını yapıtlarında barındırdıkları için ön-Rönesans döneminin primitif sanatçılarına yönelmişlerdir. Hemen sonrasında on dokuzuncu yüzyılın ortalarında Nasıralıların amacına benzer bir kaygıyla İngiltere'de Pre-Raphaelite Brotherhood (ÖnRafaelciler kardeşliği/ birliği) ortaya çıkar. Bu sanatçılar, Rafaello ile birlikte sanatta aşırı bir idealleştirmenin başladığı ve güzellik adına gerçeklikten uzaklaşıldığı için Rafaello öncesindeki daha samimi ve inançlı döneme gidilmesi gerektiğini öne sürerek kendilerine bu dönemi ima eden ismi koymuşlardır. Royal Akademide eğitim gören bu birlik üyeleri "Akademik geleneği reddederek, Gotik sanata ve Quattrocento’ya (İtalya'nın XV. Yüzyılı) yaklaşmak istiyorlardı" (Cassou, 1987: 44-45). 0 dönem sanatçılarının üslubunu tam anlamıyla taklit etmekten çok sanata yaklaşımlarındaki içtenliği önemseyen grup üyeleri, parlak renk tercihi ve detaycı yaklaşımlarıyla doğa, tarih, kutsal kitap, efsaneler ve edebi metinlerden esinlenerek gizemci bir yaklaşım sergilemişler ve bu tutumlarıyla sembolizmin de öncüsü olmuşlardır. Ön-Rönesans ve Gotik sanattan etkilenerek ortaya koydukları titizlikten ödün vermeyen detaycı teknikleri sayesinde dekoratif sanatların yeniden doğuşuna da katkıda bulunmuşlardır. 
Sembolistler açılan bu yoldan ilerlemiş̧lerdir. Düşünsel yanı ağır basan, özgün, bireysel boyuta sahip olmayı amaçlayan sembolist sanatçıların doğal öncüsü Gaugin sayılır. Paul Gaugin endüstrileşen ve maddileşen modern yaşamdan uzaklaşarak egzotik dünyanın primitif boyutunda sanatın kaynaklarına inmeye çalışmıştır. Bu anlamda yüzeyin vurgulanması, saf ve parlak renk kullanımına destek veren biçimsel çözümler ve bunlara yüklenen sembolik anlamlar (örtülü anlatım) sembolist resmin karakteristik özelikleridir. Pre-Raphaelistlerde kendini gösteren sanatın dekoratif boyutuna sembolistler de önem vermişlerdir. Onlara göre nihai bir sonuç olarak "sanat yapıtı dekoratif olmalıdır, çünkü gerçek anlamıyla dekoratif resim, Mısırlılar’ın, büyük bir olasılıkla da Grekler’in ve Rönesans öncesi sanatçıların kavradıkları gibi, aynı anda öznel, sembolist ve düşünceci olan sanatın belirtisinden başka bir şey değildir” (Cassou, 1987: 52).

19. yüzyılın ikinci yarısından itibaren figür plastiğine dönük arayışlarda Ön-Rönesans'ın yol göstericiliği kaçınılmazdır. İsviçreli ressam Ferdinand Hodler (1853-1918) insanlığın yazgısına dair yalın ve yoğun bir sentez oluşturmaya çalıştığı kompozisyonlarını oluştururken eski ustaların dolaysız anlatımına başvurmuş, “özellikle Dürer, Holbein ve İtalyan Primitiflerini (Erken Rönesans sanatçılarını) önemsemiştir” (Lynton, 1982: 24). (Resim 3 ).

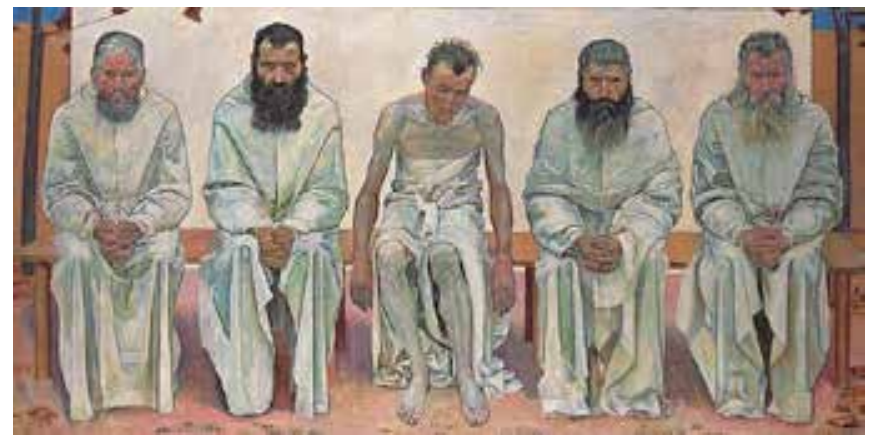

Resim 3. Ferdinand Hodler, 'Hayatın Yorgunluğu', Tuval Üzerine Yağlıboya, 149.7×294 cm, 1892

https://commons.wikimedia.org/wiki/File:Ferdinand_Hodler_Die_ Lebensm\%C3\%BCden.jpg Erişim:20.12.17

\section{Modernizm ve Sonrasında Doğal Gerçekliğin Temsili}

Modern resmin oluşumunda izlenimcilik ve devamındaki gelişmelerle ortaya çıkan soyut ve soyutlama temelli yaklaşımların yanı sıra doğal gerçeklikle daha yakın ilişkideki resimsel temsilin de kendine has bir gelişimi söz konusudur. I. Dünya Savaşı'ndan sonra avangarda olan inancın sarsılmasıyla bir- likte Paris ve diğer merkezlerde kimi sanatçılar yeniden gerçekliğe yönelmişler ve geleneksel biçimlendirme yöntemlerini tekrar değerlendirmişlerdir. Savaş pek çok sanatçının modern dünyaya duyduğu inancı sarsmış ve pek çok yerde öncü tutumlardan vazgeçilmiştir. Bu ilk modernist krizde Picasso ve Derrain da dahil olmak üzere nesnelliğe ve gerçekliğe yönelen sanatçılar olmuştur (Resim 4). Bu hareket 'düzene dönüş’ (return to order / rappel a l'orde) olarak adlandırılır. Kimi zaman yeni klasikçi olarak da nitelendirilen bu sanatçılar Giotto ve ön-Rönesans ressamlarına yeni bir gözle yeniden bakmaya başlamışlar, gelenekle bağlantı kurmak yeniden gündeme gelmiştir. Geleneksel resimsel değerler aracılığıyla yeniliğin yaratılabileceğinin kanıtı olarak Henry (Gümrükçü) Rousseau (1844-1910) gösterilmiştir. Akademi dışı, naif bir karaktere ve belli bir yoğunluğa sahip bu resimler sayesinde nesnelerin görünüşü yeniden önem kazanmıştır. Andre Derrain (18801954) Fovist denemelerinden sonra Cezanne'ı çağrıştıran sağlam yapısalcı kurgusu ve perspektif kurallarına uymayan düzenlemeleriyle Ön-rönesans resimlerine gönderme yapan çalışmalar gerçekleştirmiştir.

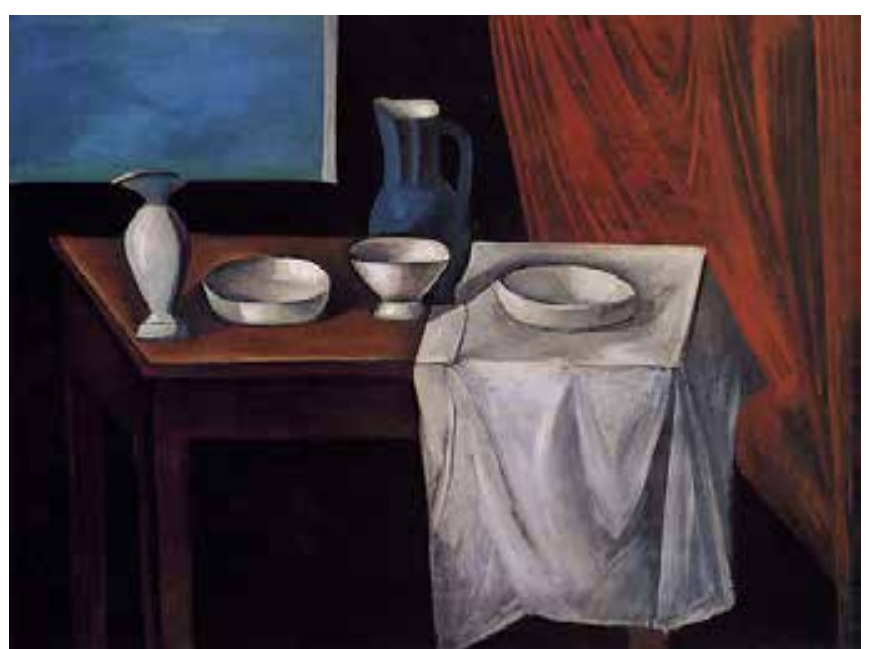

Resim 4. Andre Derrain, 'Masa / La Table’, 1911, Tu., Üz.,Yb., $96.5 \times 131.1 \mathrm{~cm}$, New York

https://en.wikipedia.org/wiki/Andr\%C3\%A9_Derain\#/media/ File:Andr\%C3\%A9_Derain,_1911,_La_Table_(The_Table),_oil_ on_canvas,_96.5_x_131.1_cm,_Metropolitan_Museum_of_Art.jpg Erişim: 27.04.2018

Chirico da karmaşık perspektif düzenine sahip metafizik çalışmaları ile benzeri bir tutum sergilemiştir. Alman Yeni Nesnelciliği büyük oranda İtalyan Primitiflerinden beslenmiştir. Avrupa'ya geldiği ilk yıllarda kübizme ilgi duyan Diego Rivera (1886-1957) daha sonra İtalya'da 14. ve 15. 
yüzyıl fresklerini ve Pompei duvar resimlerini inceledi. Böylece Meksika'ya dönünce bu deneyimlerini Aztek ve İnka uygarlıklarının resimsel mirasıyla birleştirerek özgün bir resimsel üslup ortaya koymuştur. Grant Wood (1891-1942), Charles Sheeler (1883-1965) ve Edward Hopper (1882-1967) gibi Amerikalı sanatçılar da avangardın şok etkisini yaşamak için değil, geriye dönüşün tesellisini yaşamak için Avrupa'ya gelmiştir. Hopper Paris'e İzlenimcilik, Cezanne veya kübizmi değil de Manet ve Courbert'i incelemek için gelmiştir. Charles Sheeler Quattrocento yapitlarını incelemiş, Grant Wood ise Dürer ve Holbein'in yapıtlarında büyülü gerçekçiliğin izlerini bulmuştur.

İngiliz sanatçı Stanley Spencer (1891-1959), PreRaphaelitlerden etkilenmiş, sağlam akademik eğitimi sayesinde eski duyarılıkları özümsemiş, günlük hayattan alegorik ve efsaneleri çağrıştıran kompozisyonlar oluşturabilmiş bir sanatçıdır. İtalyan Primitiflerinin ilkel duyarııı̆ına sahip olan sanatçının çalışmalarında, özellikle Piero Della Francesca'nın sağlam yapısalcılığının izlerine rastlamak mümkündür (Resim 5).

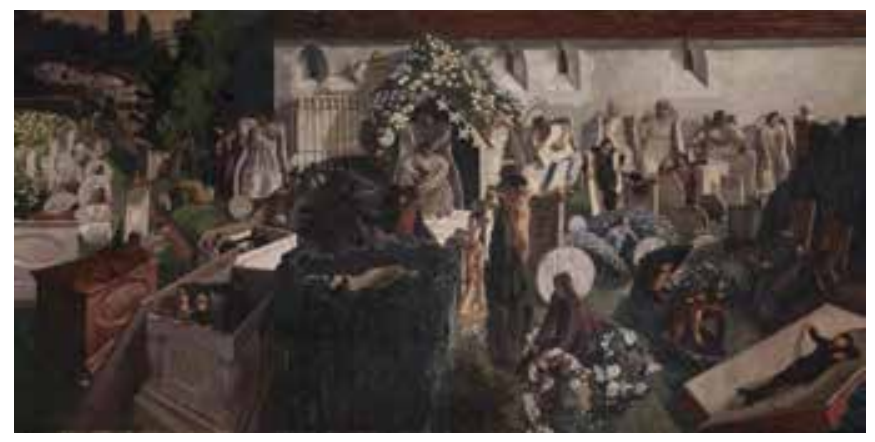

Resim 5. Stanley Spencer, 'The Resurrection / Diriliş, Cookham', Tuval Üzerine Yağlıboya, $274.3 \times 548.6$ cm., 1924-27, Tate Museum, Britain.

http://www.tate.org.uk/art/artworks/spencer-the-resurrectioncookham-n04239 Erişim:20.12.17

Gerçekliğin algılanmasında bilinç dışı unsurları devreye sokan, bu anlamda psikanalizden yararlanan, iki dünya savaşı arasındaki en önemli akımlardan birisi olan sürrealizm içinde yer alan birçok ressam, geleneksel sanatın eski ustalarının biçimlendirme yöntemlerinden yararlanmıştır. Dadanın absürd tutumunu, metafizik resmin tuhaflığıyla birleştiren ve rüyalara önem veren sürrealizmde "bilinç dışının açıkça tek ilham kaynağı olarak görülmeye başlamasıyla, bilinç dışı kavrayış ile bilinçli algı arasındaki ayrım yaratıcı bir biçimde ortadan kalkmıştır" (Kuspit, 2006: 116). Ancak yeterince değerlendirilemeyen sürrealizm, modernist süreçte hafife alınmış, kübizme dayalı soyutlamacı dönemlerde bastırılmış ve görmezden gelinmiştir. Eski ve geleneksel bir görsel dil kullandığı için "Anglo-Amerikan biçimciliğinde gerçeküstücülük sapkın bir sanat akımı sayılıyordu: Görselliği uygunsuz, edebiliği haddini bilmez, biçimin mecburiyetine karşı nispeten özensiz, janr yasalarına karşıysa çoğu zaman aldırışsız olan, çocukça haller ve gözden düşmüş formlarla ilgilenen paradoksal bir avangarddı; hiç de layıkıyla modernist değildi” (Foster, 2011: 12). Sürrealist resimde temsil, geleneksel resimdeki gibi doğrulama ve benzerlik koşullarına dayanmaz. Bu durum soyut sanatla (Kandinsky) ve Magritte'in (Resim 6) simülatif yorumlarıyla aşılmıştır.

Magritte simülasyonlarında... benzerliği doğrulamadan kurtarır. Burada benzerlik ve benzeşme muhafaza edilse de, doğrulanan hiçbir gerçeklik yoktur... Magritte eski temsil uzamının hüküm sürmesine ancak yüzeyde izin verir... altında hiçbir şey yoktur. Bu tür gerçeküstücü sanatta temsil yeniden ortaya çıkar gibi görünür yalnızca; aslında simülasyonla tekinsiz olarak geri döner (Foster, 2011: 124-125).

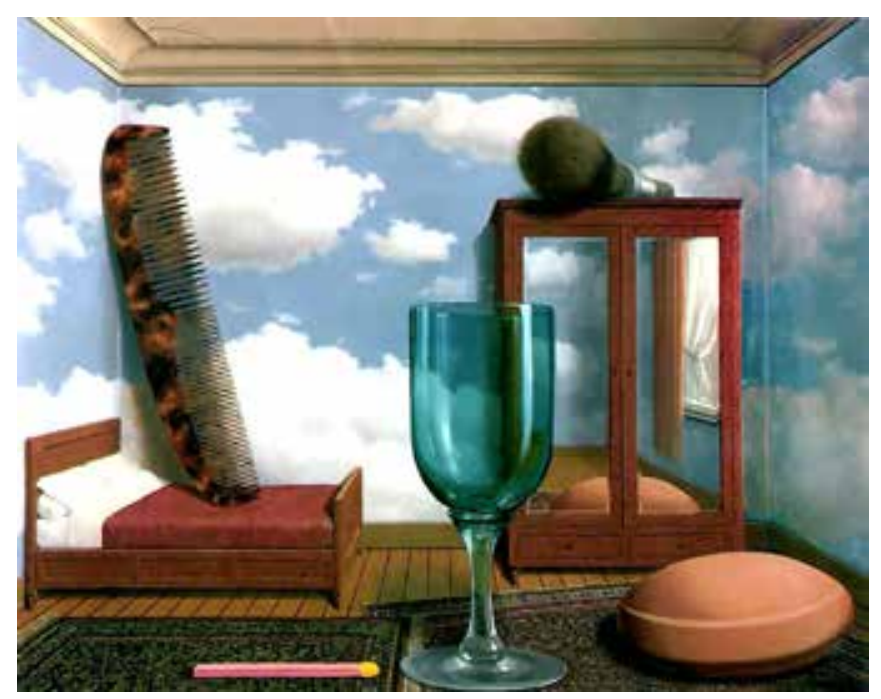

Resim 6. Rene Magritte, ‘Kişisel Değerler’, 1952, Tuval Üz.Yağlıboya, $77,5 \times 100 \mathrm{~cm}$.

https://www.renemagritte.org/personal-values.jsp Erişim: 27.04.2018

Postmodern süreci önemseyen ve savunan Hal Foster, Greenberg'cü modernizmin aşılmasından sonra gerçeküstücülüğe yeniden yer açıldığını, postmodern sanatın temsil eleştirisi için geçmişe yönelik önemli bir referans noktası haline geldiğini öne sürer. “1980’lerde bu eleştiri çoğu 
kez, bilhassa medya imgelerinde görülen alegorik sahiplenmeler üzerinden iletildi. Kimliğin cinsellikle bulandırılması gibi, gerçekliğin benzetim aracılığıyla bulandırılmasını da gerçeküstücüler üstlenmişti ve bu sorunsala bulaşmak, bu sanata merak salmak demekti” (Foster, 2011: 14).

Modernizmin sonunu Greenberg'ün insan ve toplumu devre dışı bırakan pür soyut resim iddiası getirmiştir. “Greenberg'ün soyut anlayışı içe dönük insanın ruhsal dünyasını da araştıran bir karşı oluşu da reddederek, resim ve sanatın toplumla olan tüm bağlarını koparmaya yöneliktir ve sanat, yalnızca estetik bir olguya dönüştürülmektedir. Bu görüş pek çok insan için modernizmin sonu anlamına gelmiştir” (Giderer, 2003: 48-49). Modernizm sonrasındaki postmodern süreç, sanatın ya da resmin sonu söylemlerine paralel olarak başlamıştır. Arthur C. Danto 1965 te Andy Warholl'un diğer birçok şeyle birlikte Brillo kutularının birebir kopyalarını sergilemesiyle birlikte sanatın sonuna gelindiğini ilan etmiştir. Artık bundan sonra "ortaya nasıl bir sanat çıkarsa çıksın, güven tazeleyici bir anlatıya sırtını dayayamayacak, böyle bir anlatının içinde öykünün bir sonraki uygun aşaması olarak görülemeyecekti. Sona eren işte bu anlatıydı" (Danto, 2010: 26). Danto postmodern dönemin sanatını 'tarihsel sonrası sanat' diye adlandırır. Baudrillard ise gerçekliğin yerini alan simülasyonlar nedeniyle daha karamsar bir modern sonrası tablosu çizer. Kuspit 'postsanat' diye adlandırdığı postmodern dönem çalışmalarını sert bir dille eleştirir; "Postmodernizmde sanat üzerine sanat anlayışı yaygındır, bu da sanatın narsisist çöküşüne işaret eder, çünkü sanat üzerine sanat, sanata ilişkin hiçbir yeni kavrayış sunmaz, ironik bir dönüştürmeyle eski sanatı yeniden üretir, bu sırada da anlamını yok eder" (Kuspit, 2006: 69).

Postmodern süreç bir yandan resme alternatif temsil olanaklarını (kavramsal sanat, land art, enstalasyon, happening, süreç sanatı, body art v.b.) üretmişken öte yandan gerçekçi temsil ve figür resmine dönük yeni hareketlerin de ortaya çıkmasına neden olmuştur. “...1960’lardan beri sanatın bir kolu - süper-gerçekçiliğin (foto-gerçekçilik) çoğu, kısmen pop-art ve temellük sanatı - gerçekçilik ve yanılsamacılığa yönelir” (Foster, 2009: 162). Pop art, bilindiği gibi Amerikan soyut dışavurumculuğunun elitizmine, biricikliğine ve Greenberg avangardizmine karşı sıradan, günlük veriler ve popüler imgelerle verilen bir tepkidir. “New York popu, Greenberg'in reddettiği ne varsa -kitsch, low-art, popüler kültür, kitle kültürü, meta estetiği vb. - hepsini meşrulaştıracak ve yüceltecek; savunduğu ne varsa - modernizm, elitizm, high art vb.- karş1sına alacaktır" (Artun, 2012: 34). Pop artın bir uzantısı olarak gelişen foto-gerçekçilik akımının ressamları da günlük yaşam ve tüketim kültürüne dair imgeleri ele almışlar, bunların fotoğraf gerçekliğini nesnel ve yansız bir tutumla kopyalamayı amaçlamışlardır. Bu sanatçılar her ne kadar ele aldıkları konuya karşı yansız ve aldırışsız davranmaya ve üsluba dair her şeyi ortadan kaldırmaya çalışmış olsalar da elle biçimlendirmenin ortaya çıkardığı üslupsal ve büyüsel sonuçlardan kaçamamışlardır. Geleneksel temsil resminin göz aldanımı (trompe l'oeil) tavrını çağrıştıran foto-gerçekçilik (Resim 7) Hal Foster’a göre gerçeküstücülükle yeraltından bir bağlantıyı devam ettirir,

...gerçeği ifşa etmektense, daha çok onu saklamak ister... süper-gerçekçilik 'bakış tarafından çaresiz bırakılan gözün' sanatı olarak kalır...Bunun sonucunda süper-gerçekçiliğin yanılsaması yalnız bir göz aldanması yaratmakta değil; bakışın dizginlenmesinde ve travmatik gerçeğe karşı savunmada da başarısız olur. Yani bize gerçeği hatırlat/ma/makta başarısız olur ve bu şekilde kendisi de travmatiktir; Bu travmatik yanılsamacılıktır (Foster, 2009: 183).

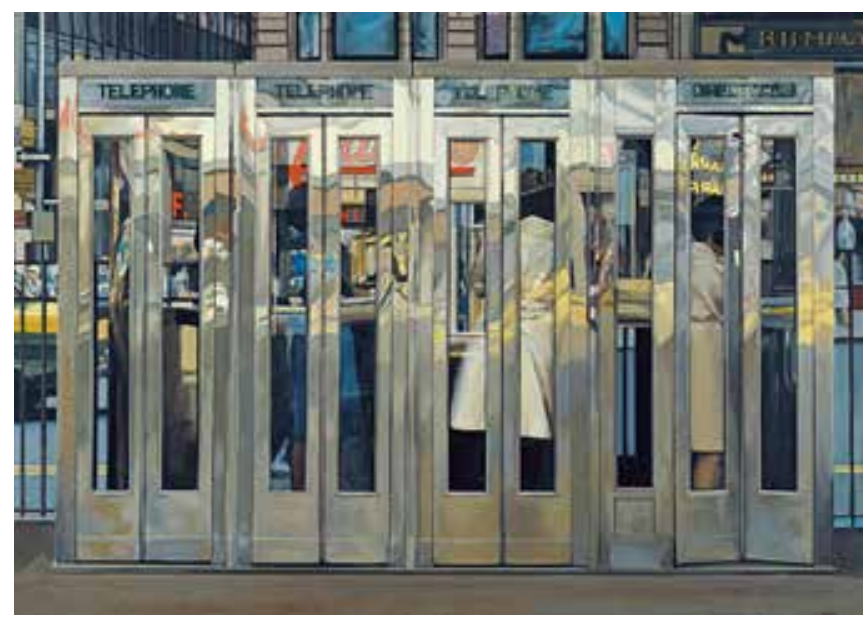

Resim 7. Richard Estes, 'Telefon Kabinleri', Fiber Levha Üzerine Akrilik, 122x175,3 cm,1967

https://www.google.com/search?newwindow $=1 \&$ tbm $=i s c h \& q=R$ ichard\%20Estes\%20Telephone\%20Booths\%20(1968)\#imgrc= SCoeDx1RN0s8M: Erişim: 27.04.2018

1960 'larda ortaya çıkan toplumsal hareketler sonucunda sanatsal ve siyasi alanlarda gerçekçilik yeniden önem kazanmaya başlamıştır. Fransa'da Yeni Gerçekçiler adı verilen ve eyleme dayalı çalışan bir grup sanatçı yeni-dada, pop ve kavram. 
sal sanattan etkilenerek çalışırken, aynı dönemde İngiltere ve Amerika'da tam anlamıla gerçekçi resim yapan, gözlemlenen gerçekçiliğe bağı kalarak çalışan ressamlar da 'Yeni Gerçekçiler’ olarak nitelendirilmiştirler. Aslında bu sanatçılar soyut sanatın egemenliği boyunca varlıklarını sürdürmüşler, 60’ların sonunda figürasyonun tekrar kabul görmesiyle yeniden gündeme gelmişlerdir. William Bailey (1930-...), Alex Katz (1927...), Neil Welliver (1929-2005) ve Lucian Freud (1922-2011) bunlardan bazılarıdır. Freud daima önünde duran konuya bağlı olarak çalışmasıyla bilinir ve çağdaş figür resminin en etkili temsilcilerindendir. Yine etkili bir İngiliz sanatçı Jenny Saville (1970-...) özgün figür yorumlarıla Freud'un ardılı gibidir. Philip Pearlstein (1924-...) ise 1950'lerin ortalarından itibaren kararlı bir biçimde ele aldığı soğukkanlı ve stilize çıplak figür yorumlarında (Resim 8) eski ustalara saygısını esirgemez. Resimsel kadraja ilişkin sıra dışı yaklaşımı ve renk ve biçimdeki özgün üslupçu tutumu onu gelenekle kurduğu bağ üzerinden güncele taşır. David Hockney eski ustalarla bağlantısını güncel boyutta gerçekleştiren bir diğer önemli sanatçıdır.

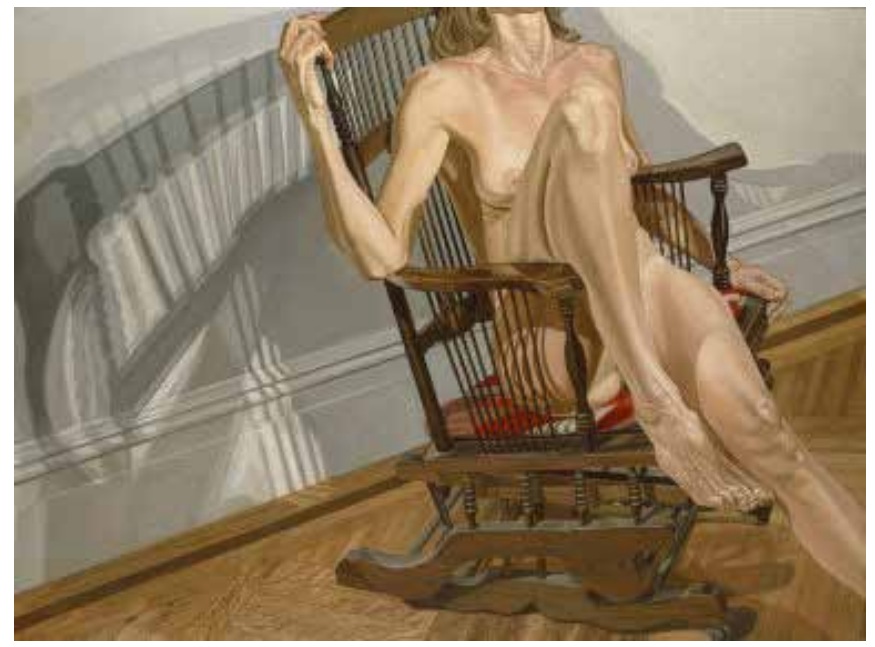

Resim 8. Philip Pearlstein, 'Sallanan Sandalyede Bayan Model', 1977-1978. Oil on canvas,

183.5 x $244.2 \mathrm{~cm}$. https://www.brooklynmuseum.org/opencollection/objects/1600 Erişim: 27.04.2018

Sanat yapıtının biricikliğinin ve yaratıcı özne olarak ben kavramının eleştirel bir biçimde sorgulandığı postmodern dönemin temsil olanakları çeşitlilik gösterir. Ekletizm, pastiş, ironi, montaj, temellük bunlardan bazılarıdır. Kısaca kendine mal etme olarak tanımlanan temellük sanatı postmodern sanat pratiklerinin merkezinde yer alır. "Temellük başı başına bir sanat olarak değerlendirilmekle birlikte, baskın olarak modernliğin orijinalite takıntısına karşı geçmişin bütün sanatsal formlarını yeni olan ile sentezleyen postmodern sanatın eklektik tavrı ile özdeşleştirilmektedir" (Koca ve Selvi, 2017: 32). Kopya ve espri kopya anlamında kullanımı geçmişe dayanan temellük, bir sanatçının veya üslubun taklit edilmesi yoluyla eski ustaların ifade yöntemlerinin kavranması veya onların çağdaş yöntemlerle yeniden yorumlanması amacıyla başvurulan bir yöntem olmuştur. Postmodern süreçte ise alıntılama veya alıntı sanatı uygulamaları aracılığıyla çeşitlenerek varlığını sürdürür. Alıntılar sadece geçmişin sanatından değil medya başta olmak üzere çeşitli kültürel mecralardan gerçekleştirilir. 1970'ler ve 80 'lerden bu güne temellük sanatının fotoğraf, medya, resim gibi alanlardan belli başlı temsilcileri Sherie Levine, Louis Lawler, Barbara Kruger, Cindy Sherman, Richard Prince, Barbara Ess, Andre Durand, Herman Braun Vega, Russell Connor, Vik Muniz, Mike Bidlo gibi sanatçılardır. Russell Connor (1929-...) geleneksel resim dilini kullanarak temellük sanatını başarılı bir biçimde kullanır. Sergei Gilbaut'un sanatın merkezinin New York'a kaymasıyla ilgili eleştirel kitabından hareketle gerçekleştirdiği Modern Sanatın New Yorklular Tarafından Kaçırılması adlı çalışması (Resim 9) bu konudaki iyi örneklerden birisidir. Sanatçı burada “Picasso'nun Avignonlu Genç Kızlar adlı resminden devşirdiği kadın figürlerini Rubens'in Leucippus'un Kızlarının İğfali resmindeki kadınların yerine iliştirmiştir...Rubens'in çalışmasındaki ikizleri talancı New Yorkluları, Picasso'dan devşirdiği kadın figürlerini ise modern sanatı temsilen kullanmıştır” (Koca ve Selvi, 2017: 43).

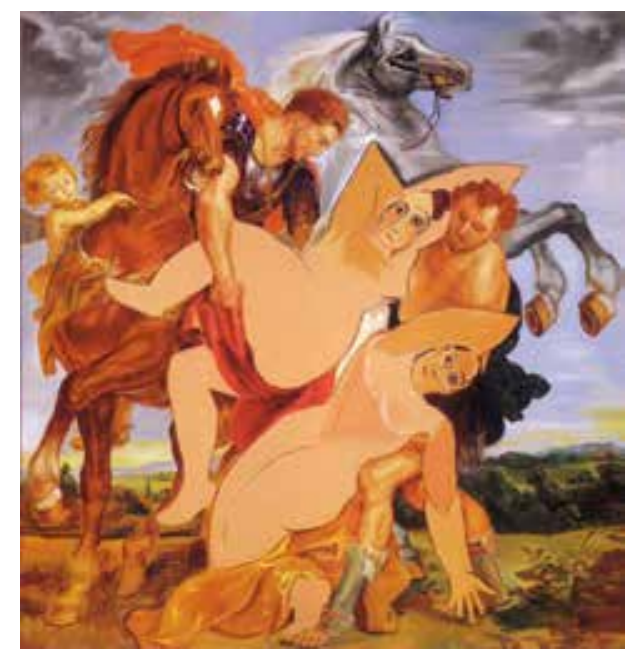

Resim 9. Russell Connor, 'Modern Sanatın New Yorklular Tarafından Kaçırılması', 1985,

172,72x162,56 cm. http://www.russellconnor.com/gallery_17. html Erişim: 27.04.2018 
Geleneksel resim dilinin ya da gerçekçi temsilin kavramsal boyutta güncel kullanımına dair önemli bir örnek Komar ve Melamid ikilisinin çalışmasıdır (Resim 10). 1994 yılında The Nation dergisinin de desteğiyle "insanların gerçekte aradığı sanat türünü bulmak üzere gerçek bir piyasa araştırması yürütmeye karar verdiler...ve 'Amerika'nın en çok arananı' adını verdikleri, tercih edilen nitelikler arasından sanatçıların tek bir tuvale sokabildiği kadar çoğunu içeren bir tablo ürettiler” (Danto, 2010: 253-254). Bu çalışma geleneksel üslubun güncel kullanımının yanı sıra sanatçıların ortaya koymuş oldukları performans olması açısından da önemlidir. Komar ve Melamid bu çalışmanın varyasyonlarını daha sonra diğer ülkeler bazında da gerçekleştirmişlerdir

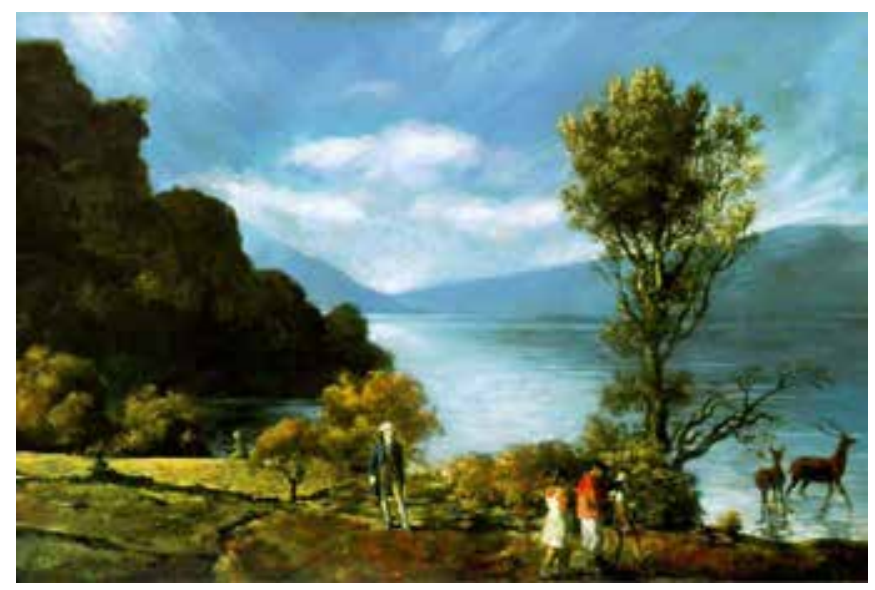

Resim 10. Komar ve Melamid, 'Amerika’nın En Çok Arananı', 1995 https://www.forbes.com/sites/jonathonkeats/2013/11/14/ french-museum-shows-americas-most-wanted-painting-aspainted-by-two-russians/\#7511e7e87ca8 Erişim:27.04.2018

1980’lerde resim ve heykelde geleneksel değerlere önem veren Yeni dışavurumculuk akımı Avrupa, Avustralya ve Amerika'da etkili olmuştur. En güçlü etkisi de Almanya ve İtalya'da görülmüştür. Bu sanatçıların çalışmalarında postmodernizmin tipik biçimlendirme yöntemleri (pastiş, tarihsel resim, kültür resmi, eklektizm, kolaj, anlatı sanatı, kitsch) varlığını hissettirir. Belli başlı isimler Georg Baselitz, Sandro Chia, Francesco Clemente, Enzo Cucchi, Eric Fischl, Jörg Immendorff, Anselm Kiefer, David Salle, Julian Schnabel gibi sanatçılardır. İtalya'da ortaya çıkan Pittura Colta (Kültür Resmi) müzelerde yer alan eski resimlerden alıntılara dayanır ve en önemli temsilcisi Carlo Maria Mariani’dir (1931-...) (Resim 11). Kitsch üslubu özel mitolojiler ve anlatı sanatı bağlamında ele aldığı çalışmalarında Odd Nerdrum (1944-...) geleneksel resim diline başvurur.

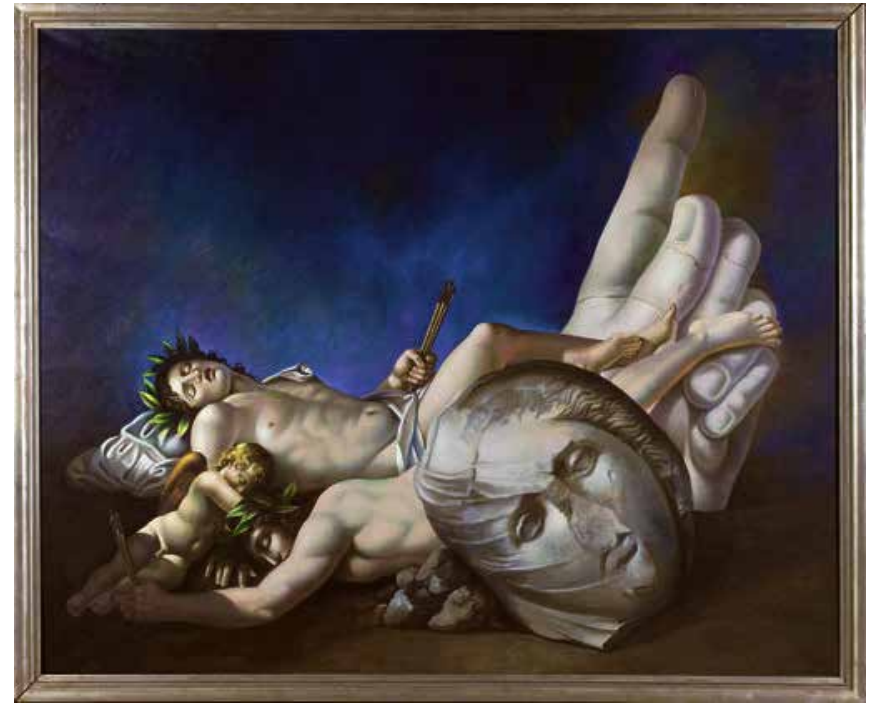

Resim 11. Carlo Maria Mariani, 'E Vietato ridestare gli dei',1984, tu.üz.yb. $200 \times 250 \mathrm{~cm}$.

https://www.christies.com/lotfinder/Lot/carlo-maria-mariani-neen-1931-4904592-details.aspx Erişim:27.04.2018

Postmodernizme karşı yoğun eleştirilerde bulunan Kuspit gelenekle bağlantılı resme olan inancının sonucu olarak postmodern sonrası sanatın 'yeni eski ustalar'ın sanatı olacağını öne sürüyor. Kuspit'e göre bu sanatçılar “hem modern hem de geleneksel sanatı ayrıntısıyla bilirler...özgünlüğün ancak eskiyi iyi bilmekle mümkün olacağına inanmaktadırlar. Geçmişin kölesi olan taklitçiler değillerdir...postmodernlerin yaptıkları gibi bu eski eserlerden mekanik olarak kolaj çalışmalarında yararlanmazlar...ilham almak için onlara yönelirler" (Kuspit, 2006: 200). Ona göre Avigdor Arikha (1929-2010), Lucian Freud, David Bierk (1942-2002), Vincent Desidero (1955), April Gornik (1953), Karen Gunderson (1943), Julie Heffernan (1956), Joseph Raffael (1933), Paula Rego (1935), Jenny Saville (1970), James Valerio (1938) gibi sanatçılar yeni eski ustalardır.

1980'ler boyunca figür temelli tuval resminin hakimiyetinden sonra 90'ların başından itibaren küratöryel faaliyetler, medya ve video sanatı gündeme gelmiştir. Ekonomik kriz nedeniyle resim alım satımının yerini sponsorluk sistemiyle çalışan güncel sanat etkinlikleri almıştır. 2000’li yılların başındaki ekonomik toparlanma ile birlikte resim sanatının yeniden önem kazanmasıyla özellikle geleneksel ve figür plastiğine dönük çalışmalarıyla Leipzig Okulu sanatçıları gündeme gelmişlerdir. Neo Rauch (1960) (Resim 12), Kai Althof (1966), Daniel Richter (1962), Matthias Weischer (1973), Tim Eitel (1971) ilk akla gelen isimlerdir. 


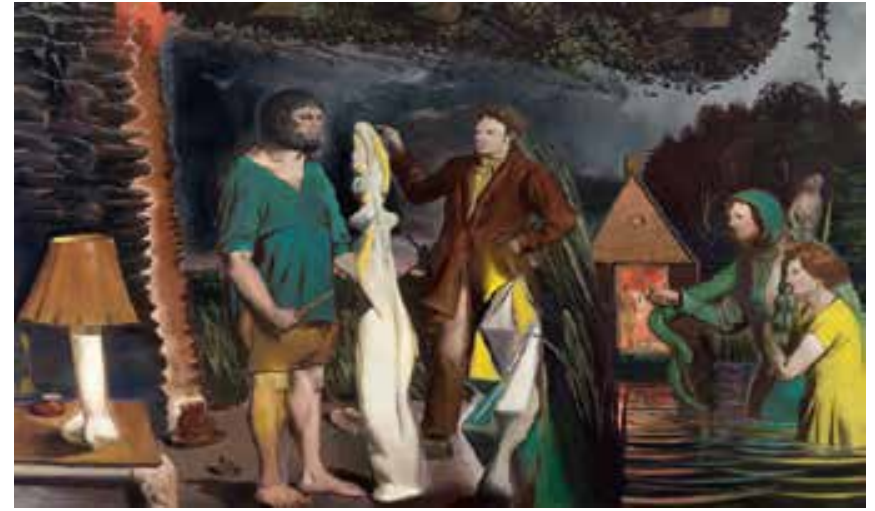

Resim 12. Neo Rauch, ‘Der Bewunderer’, 2016, Tu. Üz Yb., $200 \times 270 \mathrm{~cm}$.

http://www.eigen-art.com/index.php?article_id=103\&clang=1 Erişim: 27.04.2018

\section{Sonuç}

Ön-Rönesans, ortaçağ sanatından Rönesans'a geçiş aşamasındaki sancılı dönemin adıdır. Giotto’yla başlayan bu süreç ortaçağın dini ve sembolik ifade biçiminden Rönesans'ına beşeri sanat formlarına ulaşılana kadarki dönemi ifade eder. Doğal gerçekliğin temsili açısından sorunlu gibi görünen bu dönem çalışmaları güçlerini bu ikircikli görünümlerinden alırlar. $\mathrm{Bu}$ yönleriyle çağdaş temsil resmi ve figüratif yorumların söz konusu olduğu her sanatsal aşamada önemli bir başvuru kaynağı olmuşlardır. On dokuzuncu yüzyılın modernizm yolundaki sanat hareketleri Nazarenler, Pre-Raphaelistler ve Sembolistlerin başvuru kaynağı olmuş, iki dünya savaşı arasında avangarda inancın sarsılması sırasındaki 'düzene dönüş’ aşamasında yine referans olmayı sürdürmüştür. Sürrealist ressamların başvurduğu ifade yöntemi bu geleneğe başvurmayı gerektirmiştir. Gerçekçi temsil, postmodern süreçte yeniden gündeme geldiğinde gelenekten ve geçmişten postmodern ifade yöntemleri bağlamında yararlanılmıştır. Çağdaş sanatın yakın tarihine baktığımızda 90’lar boyunca küratörlü sergiler, medya sanatı ve video gibi disiplinler ortaya çımış, sponsorluk sistemi sanatsal prodüksiyonun bir parçası haline gelmiştir. 2000'lerin başıyla birlikte tuval resmi ve figüratif temsil yeniden gündemdeki yerini almıştır; tabi ki çoğulcu sanatsal ortam içinde bir unsur olarak... Sonuçta doğa gerçekliğinin ya da figürün iki boyutlu tuval yüzeyinde temsili söz konusu olduğu her dönemde Ön-Rönesans sanatı ve geleneksel yöntemler her zaman rehber olmayı sürdürecektir.

\section{Kaynakça}

Alp, K.Ö. (2013). “Sanatın Temsili Ve Postmodern Sanatta Temsil”, Süleyman Demirel Üniversitesi Güzel Sanatlar Fakültesi Hakemli Dergisi ART-E 12: 40-61.

Artun, A. (2012). Çağdaş Sanatın Örgütlenmesi, İstanbul, İletişim Yayınları 1653, (Sanat Hayat Dizisi 22).

Beksaç, E. ve Akkaya, T. (1990). Avrupa Resim Sanatı, İstanbul: Arkeoloji ve Sanat Yayınları.

Cassou, J. (1987). Sembolizm Sanat Ansiklopedisi, (Çev. Özdemir İnce, İlhan Usmanbaş), İstanbul: Remzi Kitabevi.

Danto, A. C. (2010). Sanatın Sonundan Sonra, (Çev. Zeynep Demirsü), İstanbul: Ayrıntı Yayınları (Sanat ve Kuram Dizisi: 26).

Faure, E. (1979). Rönesans Sanatı, (Çev. Bertan Onaran), İstanbul: Kültür Bakanlığı Yayınları: 306, Sanat Dizisi: 1.

Florenski, P. (2013). Tersten Perspektif, (Çev. Yeşim Tükel), İstanbul: Metis Yayınları.

Foster, H. (2009). Gerçeğin Geri Dönüşü, (Çev. Esin Hoşsucu), İstanbul: Ayrıntı Yayınları (Sanat ve Kuram Dizisi: 24).

Foster, H. (2011). Zoraki Güzellik, (Çev. Şebnem Kaptan), İstanbul: Ayrıntı Yayınları (Sanat ve Kuram Dizisi: 29).

Giderer, E. H. (2003). Resmin Sonu, Ankara: Ütopya Yayınevi.

Koca, B. ve Selvi. Y. (2017). “Modernizm ve Postmodernizm Sürecinde Bir Alıntılama Biçimi Olarak Temellük”, Dokuz Eylül Üniversitesi Güzel Sanatlar Fakültesi Yedi Sanat, Tasarım ve Bilim Dergisi 18: 31-50.

Kuspit, D. (2006). Sanatın Sonu, (Çev. Yasemin Tezgiden), İstanbul: Metis Yayınları.

Lynton, N. (1982). Modern Sanatın Öyküsü, (Çev. Cevat Çapan, Sadi Öziş), İstanbul: Remzi Kitabevi.

Panofsky, E. (1995). İkonografi ve İkonoloji (Renaissance Sanatının İncelenmesine Giriş), (Çev. Engin Akyürek), İstanbul: Afa Yayınları.

Panofsky, E. (2017). Perspektif: Simgesel Bir Biçim, (çev. Yeşim Tükel), İstanbul: Metis Yayınları.

Vasari, G. (2013). Sanatçıların Hayat Hikayeleri, (Çev. Elif Gökteke), İstanbul: Sel Yayıncılık.

Venturi, L. (1954). Resim (Giotto'dan Chagall'e kadar bir resme nasıl bakmalı), (Çev. Mesut Erdem), İstanbul: Doğuş Ltd. 0. Matbaası. 


\section{Görsel Kaynaklar}

Resim 1. Paolo Uccello, 'San Romano Savaşı', 1438-40, Ahşap Üzerine Tempera, $182 \times 320 \mathrm{~cm}$, The National Gallery, London

https://www.nationalgallery.org.uk/paintings/paolo-uccello-thebattle-of-san-romano Erişim: 20.12.2017

Resim 2. Piero Della Francesca, 'Diriliş’, 1460, Fresk-duvar, Museo Civico di Sansepolcro, Italy. https://www.wikiart.org/en/ piero-della-francesca/the-resurrection (Erişim: 20.12.2017)

Resim 3. Ferdinand Hodler, 'Hayatın Yorgunluğu', Tuval Üzerine Yağlıboya, 149.7×294cm,1892 https://commons.wikimedia. org/wiki/File:Ferdinand_Hodler_Die_Lebensm\%C3\%BCden. jpg (Erişim:20.12.17)

Resim 4. Andre Derrain, 'Masa / La Table’, 1911, Tu. Üz. Yb., 96. $x \quad 131.1 \quad \mathrm{~cm}, \quad$ New York https://en.wikipedia.org/wiki/Andr\%C3\%A9_Derain\#/ media/File:Andr\%C3\%A9_Derain,_1911,_La_Table_(The Table),_oil_on_canvas,_96.5_x_131.1_cm,_Metropolitan_ Museum_of_Art.jpg (Erişim: 27.04.2018)

Resim 5. Stanley Spencer, 'The Resurrection / Diriliş, Cookham', Tuval Üzerine Yağlıboya, $274.3 \times 548.6$ cm., 1924-27, Tate Museum,Britain.http://www.tate.org.uk/art/artworks/spenc er-the-resurrection-cookham-n04239 (Erişim:20.12.17)

Resim 6. Rene Magritte, 'Kişisel Değerler', 1952, Tuval Üz.Yağlıboya, 77,5x100 cm https://www.renemagritte.org/ personal-values.jsp (Erişim: 27.04.2018)

Resim 7. Richard Estes, 'Telefon Kabinleri', Fiber Levha Üzerine Akrilik, 122×175,3 cm,1967 https://www.google.com/ search?newwindow $=1 \&$ tbm $=$ isch \&q=Richard\%20Estes $\% 20$ Telephone \% 20 B o ot hs \% 20(1968)\# i m grc = . SCoeDx1RN0s8M: Erişim: 27.04.2018

Resim 8. Philip Pearlstein, 'Sallanan Sandalyede Bayan Model', 1977-1978. Oil on canvas, $183.5 \times 244.2 \mathrm{~cm}$. https://www. brooklynmuseum.org/opencollection/objects $/ 1600$ (Erişim: 27.04.2018)

Resim 9. Russell Connor, 'Modern Sanatın New Yorklular Tarafından Kaçırılması', 1985, 172,72x162,56 cm. http:// w w w. russell connor.com/gallery_ 17 . h t m l (Erişim: 27.04.2018)

Resim 10. Komar ve Melamid, 'Amerika'nın En Çok Arananı', 1995 https://www.forbes.com/sites/jonathonkeats/2013/11/14/ french-museum-shows-americas-most-wanted-painting-aspainted-by-two-russians / \# 7511 e 7 e 87 c a 8 (Erişim:27.04.2018)
Resim 11. Carlo Maria Mariani, 'E Vietato ridestare gli dei’,1984, tu.üz.yb. 200×250 cm. https://www.christies.com/lotfinder/ Lot/carlo-maria-mariani-ne-en-1931-4904592-details.aspx (Erişim: 27.04.2018)

Resim 12. Neo Rauch, 'Der Bewunderer', 2016, Tu. Üz Yb., $200 \times 270 \mathrm{~cm}$. http://www.eigen-art.com/index.php?article_ $\mathrm{id}=103 \&$ clang=1 (Erişim: 27.04.2018) 